\title{
A Study on Effects of Mentoring Education Program by Advisor onto Adaptation and Relationship of University Freshmen
}

\author{
Mi-Ran Lee1)
}

\begin{abstract}
The identity of each university is threatened due to severe changes in the university entrance exam environment including a low birthrate and an increase in the drop-out rate by the students maladaptive to their majors. Accordingly, in this study, the effects of the mentoring program which was implemented during a semester targeting the university freshmen were examined and analyzed in order for the students to establish each identity as an adult and to enhance their adaptation ability to the university environment. Based from the results of the study, most of the freshmen showed very positive responses regarding some enhancement of the levels of the satisfaction with some academic courses, a help for the adaptation to the university life, a help for their understanding of each major course, some enhancement of their prides in the university, some enhancement of their interests in studying, some enhancement of the levels of closeness with each classmate and some enhancement of the learning atmosphere, etc. This study emphasized the formation of useful relationship between a mentoring program and the supervision to university freshmen. An advisor, as a mentor, will participate in the program as part of the curriculum to help freshmen adapt to the university environment. Therefore, this study is intended to suggest some baseline data for preparing for various kinds of policies on educational welfare and proposals on educational innovation in order for the future Korean university freshmen.
\end{abstract}

Keywords : University Freshmen, Mentoring Education, Adaptation to a University, Policies on Educational Welfare \& Educational Innovation

\section{Preface}

The year for university freshmen is the time when they experience many disputes and confusions due to sudden changes in the environment as a transitional period when they become adults from minors and it is required for them to adapt themselves to a new society as well as to be emotionally independent from their guardians. The fact itself that they become university students means a change of one of their roles and they face a sudden change in the educational environment and have to change their lifestyles into more independent and active ones. And university freshmen tend to feel many kinds of new types of pressure which are

Received(September 21, 2018), Review Result(1st: October 11, 2018, 2nd: November 12, 2018), Accepted(December 10, 2018)

1) (Assistant Professor) 49104 Dept. Social Welfare, Kosin Univ., 194 Wachi-Ro Yeongdo-Gu, Busan, Korea email: dsmr0815@naver.com 
A Study on Effects of Mentoring Education Program by Advisor onto Adaptation and Relationship of University Freshmen

fundamentally different from the ones that they used to have during their highschool days, such as, a need to change the passive learning attitude to the active one, a new kind of personal relationship and the social expectation felt by a university student, etc. As well, they tend to suffer from many kinds of stresses in the different environment and with many kinds of social requirements. Accordingly, many of them may have some adaptational problems in such a new environment[1].

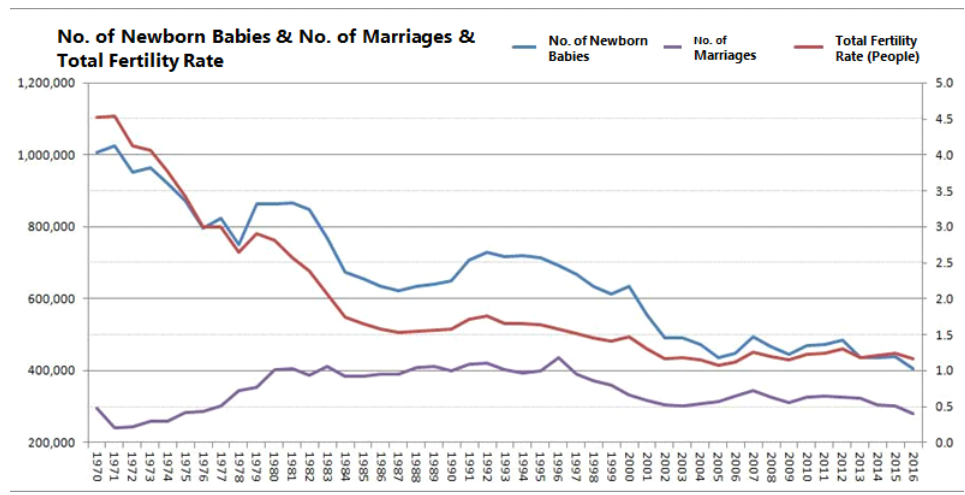

[Fig. 1] Number of Newborn Babies \& Number of Marriages \& Total Fertility Rate

Especially, the higher educational institutions entrance rate of the Republic of Korea was recorded at $70.7 \%$ in 2013 and the record is a quite a higher level compared to the average point of those of the OECD member countries[2]. Moreover, it was found that the highschool entrance rate was ranked as the top according to the Global Competitiveness Report (GCR) made by the World Economic Forum (WEF) in 2013[3].

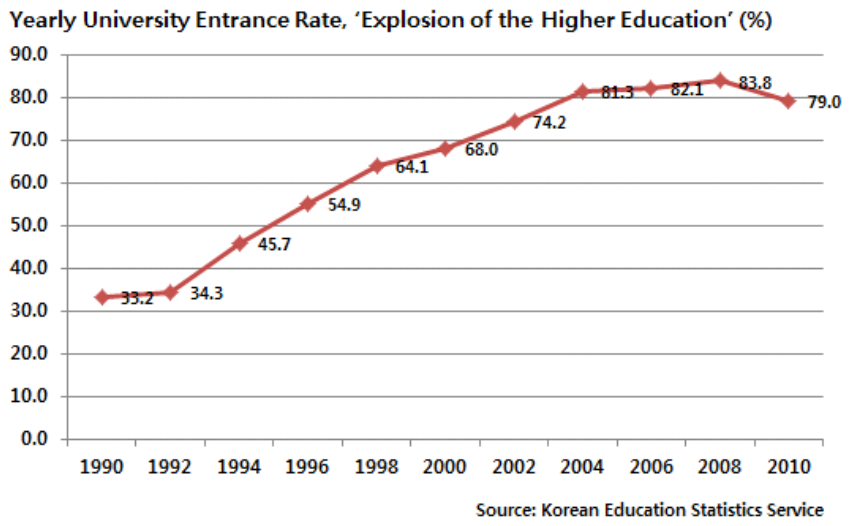

[Fig. 2] Yearly University Entrance Rate, 'Explosion of the Higher Education' (\%) 
A high entrance rate have some positive aspects. But since there are big differences between the levels of learning motivation of the students, some of university freshmen may not adapt themselves to the university environment. A maladaptation to the university environment may make a negative effect on their academic performance levels and also may make a negative effect on the effectiveness of the university education ultimately since the students' interests may be focused on many kinds of non-educational areas.

As shown in the figure 2 above and the figure 3 below, the university graduation rate of the people in their $20^{\prime} \mathrm{s}$ to $30^{\prime} \mathrm{s}$ of the Republic of Korea is the top compared to the OECD member countries as well as the highest university entrance rate[4].

Thus, many university authorities have many kinds of institutional systems by providing counseling and service programs in order to enhance the adaptive ability of each student to the university environment, but many doubts are cast onto the effectiveness of such systems[4].

In case of freshmen among the university students, their maladaptation is more prominent. Those freshmen are suddenly required to lead their autonomous lifestyles and to lead their learning lives after they become the university students after they have been accustomed to live their passive lives heteronomously according to the directives with the only goal for entering a university until their highschool days. However, they tend to express various kinds of problems, such as, difficulties in learning and problems to personal relationship, etc. led to their appeals on their anxieties and difficulties.

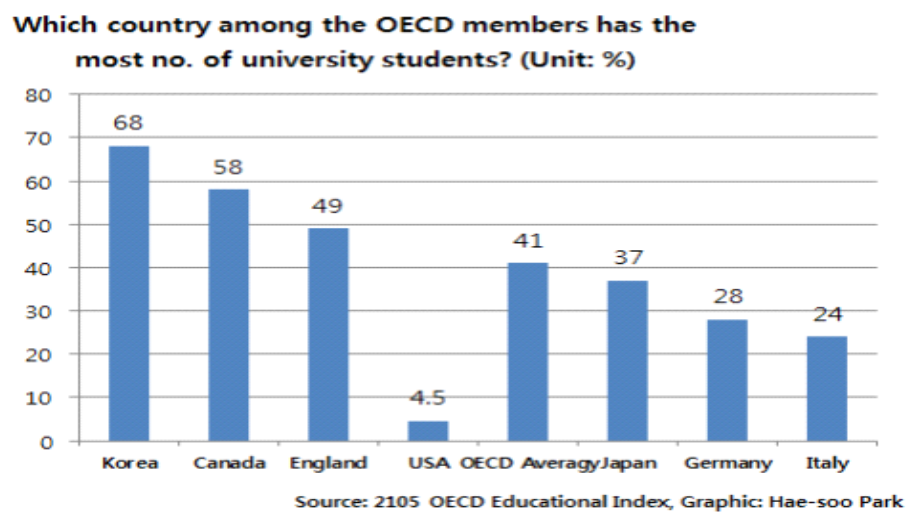

[Fig. 3] Which Country among the OECD Members Has the Most number of University Students?(Unit: \%)

It has been found that the adaptation levels of freshmen are lower than those of their senior students from most of previous studies. 
A Study on Effects of Mentoring Education Program by Advisor onto Adaptation and Relationship of University Freshmen

[Table 1] Countries Having a High Rate of University Graduates Among the OECD Member Countries

\begin{tabular}{|c|c|c|}
\hline \multicolumn{2}{|c|}{ Countries having a high rate of university graduates among the OECD member countries } \\
\hline Ranking & Country & Rate of University Graduates (\%) \\
\hline 1 & KOR & 58 \\
\hline 2 & Canada & 56 \\
\hline 3 & Japan & 55 \\
\hline 4 & New Zealand & 48 \\
\hline 5 & Norway & 46 \\
\hline 6 & Ireland & 45 \\
\hline 7 & Denmark & 43 \\
\hline 8 & Belgium & 42 \\
\hline 8 & Australia & 42 \\
\hline 8 & The USA & 42 \\
\hline & OECD Average & 35 \\
\hline
\end{tabular}

*Source: Education at a Glance by OECD

*Note: As of 2008, University Graduation Rate of the Population in the age bracket from 25 to 34

Such students who feel difficulties in adaptation to the university environment have low levels of satisfaction with their university lives naturally and their immersion levels into overall learning and they tend to their maladaptation to some major courses and university environment and their worries about the future careers[5].

Even though such university freshmen have many difficulties and problems, the previous studies targeting university freshmen have not attracted any attention of the researchers. Accordingly, the Korean government has paid many efforts and expenses for securing excellent students stably, but it has no paid attention to the experiences felt by the university freshmen once each freshman is selected.

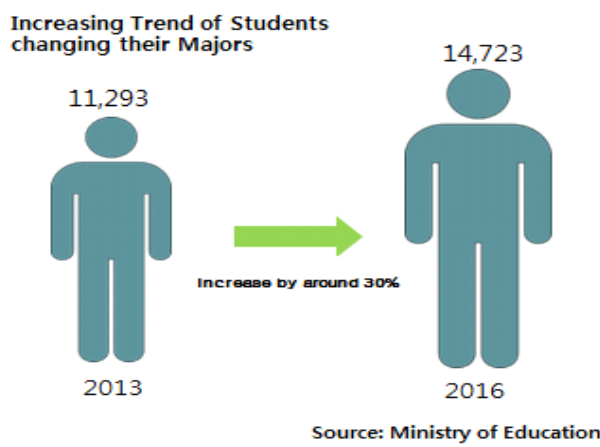

[Fig. 4] Increasing Trend of Students changing their Majors

It is in the trend that the number of university students changing their major courses is increasing nationwide. According to the statistical data released by the Ministry of Education, 
the number of students changing their major courses was 11,293students in 2013, but after that, it has increased to 14,723 students by around $30 \%[6]$.

[Table 2] Reasons why Students Regret the Selection of a Major

\begin{tabular}{|l|l|}
\hline $\begin{array}{l}\text { Ratio of the numbers of the } \\
\text { students regretting and not } \\
\text { doing the Selection of their } \\
\text { Current Majors }\end{array}$ & $\begin{array}{l}\text { Reason for Regretting the Selection of a Major (Multiple } \\
\text { Reponses) } \\
\text { Since it is different from that I thought: } 42.3 \% \\
\text { Since it is different from my aptitude: } 30.7 \% \\
\text { Since the employment rate of the graduate students from } \\
\text { the department is low: } 25.3 \% \\
\text { Since I applied for the department based on the exam } \\
\text { Scores: } 21.3 \% \\
\text { Since the department is not preferred by a company: } 17 \% \\
\text { Since there are too much to learn: } 15.1 \% \\
\text { Since it is not a science in which I can develop my } \\
\text { professionalism: } 11.6 \% \\
\text { Since the contents are far from the reality: } 11.4 \%\end{array}$ \\
$\begin{array}{l}\text { Percentage of Regrets: } 72.7 \% \\
7 \text { out of } 10 \text { students }\end{array}$
\end{tabular}

In addition, the employment rate of the science and engineering departments has exceeded 80\% since 2015[7]. Accordingly, many university students of the departments of humanities try to change a major or have a double major. Moreover, it was found that the department of the computer science is very popular recently.

However, since many students start a double major just for being employed, it is not easy to study. A student who is at the department of history and studies the Industrial Management Engineering as the double major said, "I have to study the differential and integral calculus that is felt difficult even by a student majoring in the science and engineering and have to study from the beginning of each subject of natural science. So, it is very hard to earn credits." And the student added, "I am planning to give up the study even though I wanted to study the Industrial Management Engineering as a double major since I have been interested in international trading and logistics."

If the number of students changing a major or having a double major increases, the number of applications for courses increases. Accordingly, since the number of vacant seats becomes insufficient, some people cannot take a relevant course. Especially, since there is a very high demand for the courses required for the graduation, it is highly competing between many students. In addition, the students taking a course as a double major feels hard to understand the contents. Even though there are generated many problems related to changing a major and having a double major, the government is expanding the systems. However, many people point 
A Study on Effects of Mentoring Education Program by Advisor onto Adaptation and Relationship of University Freshmen

out that the depth of learning by the students taking under-graduate courses will become shallow and the universities have become a path toward the employment of each student.

[Table 3] The Biggest Reason for Selecting the Current University

\begin{tabular}{|l|l|}
\hline $\begin{array}{l}\text { <The biggest reason for selecting the current } \\
\text { university> }\end{array}$ & <Type of University wanting to select again> \\
\hline $\begin{array}{l}\text { Since it is high possible to be admitted : 29.5\% } \\
\text { Since it is highly expected to be employed in the } \\
\text { future: } 20.5 \%\end{array}$ & $\begin{array}{l}\text { A university specializing the area I want to } \\
\text { major in: } 44.0 \%\end{array}$ \\
$\begin{array}{l}\text { Since the area wanted to be majored by me is } \\
\text { specialized: } 19.0 \%\end{array}$ & $\begin{array}{l}\text { A university having a high employment rate: } \\
\text { Due to the fame of a university/ department: } \\
\text { A university having a good scholarship system } \\
\text { and supporting benefits: } 12.5 \%\end{array}$ \\
$\begin{array}{l}\text { Due to a financial burden: } 10.5 \% \\
\text { Since it is near from my house: } 6.5 \%\end{array}$ & $\begin{array}{l}\text { A university whose tuition fee is low: } 14.5 \% \\
\text { Others: } 5.5 \%\end{array}$ \\
Others; $2.0 \%$ &
\end{tabular}

According to DAEHAKNAEIL 20'S INSTITUTE, it was found that 1 out of 3 university freshmen $(35.5 \%)$ recognizes that the university is not the one they wanted to join before being admitted. Based on the results of a survey and a face-to-face interview with 213 university freshmen in 2013 nationwide, when they select a university, if his/her own opinion is not reflected much, the rate of the students being satisfied with the university is very low at $11.8 \%$. On the other hand, it was found that the higher the satisfaction levels with a university and a department, the higher the satisfaction level with the university life[8].

What is the biggest problem of the university freshmen? $29.5 \%$ of the respondents chose many learning problems as a major cause of stress followed by the economic problems $(20.0 \%)$, the problems related to career and employment (18.5\%), etc. in the descending order. Regarding to the question on when they feel that it is no need to pay any tuition fee, $25.5 \%$ of the respondents felt it when a lecture is poor, $17.0 \%$ when there are no lectures wanted by the respondent and $17.0 \%$ when they really feel that it is hard to get a job after graduating, etc. Thus, it was found that they are very sensitive to the learning problems[9].

The times when the number of students is reduced every year has come. Accordingly, even though each university is urgent to fill the maximum number of students, it is not only a problem to attract freshmen, but also the number of students giving up studying is increasing. If the recruiting rate of the enrolled students can be increased, the drop-out rate must be reduced. It is the time necessary to review overall education service being provided to the enrolled students. 
Status of Dropouts of Universities Nationwide

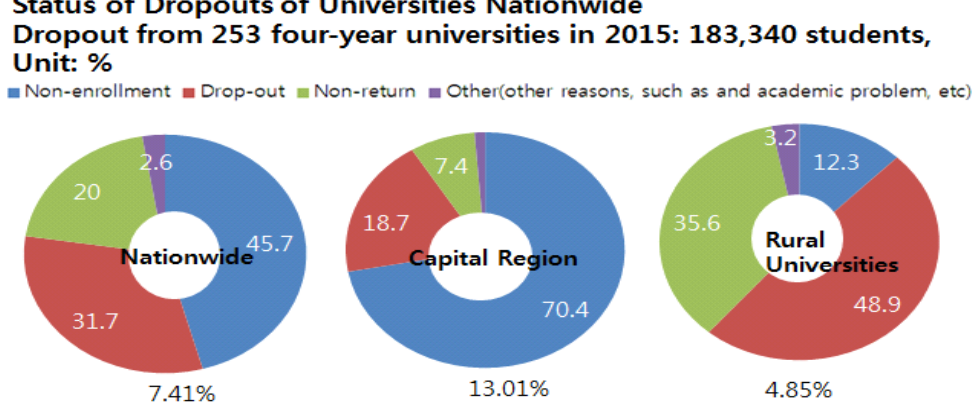

Drop-Our Rate compared to the total enrolled students

[Fig. 5] Status of Dropouts of Universities Nationwide

source: A Dilemma in the Year of Increased University Freshmen , 2017, 'Drop-Out Rate' March 28,

As having been examined above, it is highly necessary to have a mediation program for helping the university freshmen suffering from a transitional situation to adapt themselves to the university environment and to study at each university. And it is considered that it is necessary to analyze the mentoring program that is implemented under the mediation program. Therefore, this study is intended to examine the effectiveness of the mentoring program that can satisfy the situations and needs of the university freshmen onto the participants in order for them to adapt themselves to the university environment and this study is meaningful in the aspect that this study provides some baseline data necessary for preparing for various policies for supplementing and some methods for educational innovation in order for the future Korean university freshmen to adapt themselves to the university entrance exam environment which is changing continuously.

\section{Study Method and Results}

This study is intended to examine the effects of the mentoring program being implemented in order for the university freshmen to adapt themselves to the university environment who face an important point of time in the aspect of the learning environment. The target group of this study is the domestic university freshmen and the parent group is the freshmen of $\mathrm{K}$ University located in a metropolitan city. The mentoring program is operated as a course for which one (1) credit is given after being selected as a required course for freshmen during the first semester in order to enhance the participation rate and the effect of the program. The 
A Study on Effects of Mentoring Education Program by Advisor onto Adaptation and Relationship of University Freshmen

contents and operation of the course have been decided by the mentoring professor at his/her discretion to be appropriate for the intention. In this study, 120 freshmen in total including 60 as the participants and 60 as the non-participants in the mentoring program were surveyed and 20 out of the participants were selected separately to be interviewed and they were surveyed on the effects onto the university lives and the future directions of the mentoring program for freshmen. The statistical areas of the questionnaire were divided into the departments, gender, the participants and non-participants in the mentoring program. In the statistical data for each department, the freshmen at all of four departments showed high levels of satisfaction with classmates, professors and departments. And the freshmen in S-, A- and K-departments answered that they feel an increase in their interests in the self-development. On the other hand, more number among the ones in G-department didn't feel it. It was found that much more number of freshmen in S-department said 'Yes' rather than 'No' to the questions on the enhancement of self-esteem, the enhancement of passion to studying, the interests in employment, the certainty in the future area of work and releasing of fear.

[Table 4] Create a Learning Atmosphere

Create a learning atmosphere

\begin{tabular}{|c|c|c|c|c|c|c|c|c|c|c|c|c|c|c|c|c|c|}
\hline \multirow[t]{2}{*}{$\mathrm{N}$} & \multirow{2}{*}{$\begin{array}{c}\text { Overall } \\
\text { average }\end{array}$} & \multicolumn{2}{|c|}{$\begin{array}{c}(1) \\
\text { S Dop. }\end{array}$} & \multicolumn{2}{|c|}{$\begin{array}{c}\text { (2) } \\
\text { A Dep. }\end{array}$} & \multicolumn{2}{|c|}{$\begin{array}{c}\text { (3) } \\
\text { G Dop. }\end{array}$} & \multicolumn{2}{|c|}{$\begin{array}{c}\text { (4) } \\
\text { K Dop. }\end{array}$} & \multicolumn{2}{|c|}{$\begin{array}{c}\text { (5) } \\
\text { T Dop. }\end{array}$} & \multicolumn{2}{|c|}{$\begin{array}{c}(6) \\
\text { E Dep. }\end{array}$} & \multicolumn{2}{|c|}{$\begin{array}{c}\text { (7) } \\
\text { D Dep. }\end{array}$} & \multirow[t]{2}{*}{ F } & \multirow[t]{2}{*}{ Post-test } \\
\hline & & $M$ & SD & $\mathrm{M}$ & $S D$ & $\mathrm{M}$ & $\mathrm{SD}$ & $M$ & $\mathrm{SD}$ & $\mathrm{M}$ & SD & $\mathrm{M}$ & SD & $M$ & SD & & \\
\hline 2.346 & 3.89 & 3.79 & .95 & 4.11 & .99 & 3.77 & 1.06 & 4.02 & 1.0 & 3.91 & 1.01 & 3.66 & .95 & 4.62 & .61 & $10.75 * * *$ & $\begin{array}{c}2>6 \\
2,4>3 \\
7>1,2,3.4 \\
5,6\end{array}$ \\
\hline
\end{tabular}

[Table 5] Interest in Study

\section{Interest in study}

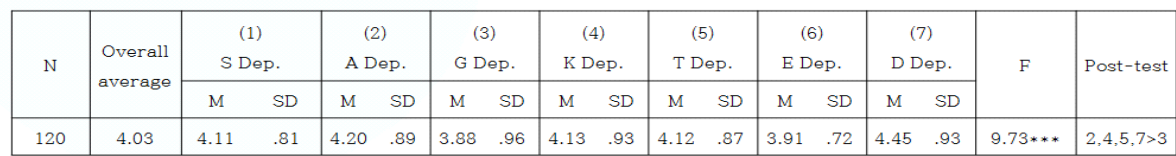

[Table 6] College life adaptation

College life adaptation

\begin{tabular}{|c|c|c|c|c|c|c|c|c|c|c|c|c|c|c|c|c|c|}
\hline \multirow[t]{2}{*}{$\mathrm{N}$} & \multirow{2}{*}{$\begin{array}{l}\text { Overall } \\
\text { average }\end{array}$} & \multicolumn{2}{|c|}{$\begin{array}{c}\text { (1) } \\
\text { S Dep. }\end{array}$} & \multicolumn{2}{|c|}{$\begin{array}{c}\text { (2) } \\
\text { A Dep. }\end{array}$} & \multicolumn{2}{|c|}{$\begin{array}{c}\text { (3) } \\
\text { G Dep. }\end{array}$} & \multicolumn{2}{|c|}{$\begin{array}{c}\text { (4) } \\
\mathrm{K} \text { Dep. }\end{array}$} & \multicolumn{2}{|c|}{$\begin{array}{c}\text { (5) } \\
\text { T Dep. }\end{array}$} & \multicolumn{2}{|c|}{$\begin{array}{c}(6) \\
\text { E Dep. }\end{array}$} & \multicolumn{2}{|c|}{$\begin{array}{c}(7) \\
\text { D Dep. }\end{array}$} & \multirow{2}{*}{ F } & \multirow{2}{*}{$\begin{array}{l}\text { Post- } \\
\text { test }\end{array}$} \\
\hline & & M & SD & $\mathrm{M}$ & $S D$ & $\mathrm{M}$ & SD & $M$ & $S D$ & $M$ & SD & M & $S D$ & $\mathrm{M}$ & $S D$ & & \\
\hline 120 & 4.14 & 4.07 & .87 & 4.30 & .85 & 4.03 & .97 & 4.20 & .93 & 4.24 & .88 & 4.02 & .83 & 4.49 & .69 & $6.03 * * *$ & $2,5>3$ \\
\hline
\end{tabular}


[Table 7] Intimacy with Professors and Classmates

\section{Intimacy with professors and classmates}

\begin{tabular}{|c|c|c|c|c|c|c|c|c|c|c|c|c|c|c|c|c|c|}
\hline \multirow[t]{2}{*}{$\mathrm{N}$} & \multirow{2}{*}{$\begin{array}{l}\text { Overall } \\
\text { average }\end{array}$} & \multicolumn{2}{|c|}{$\begin{array}{c}\text { (1) } \\
\text { S Dep. }\end{array}$} & \multicolumn{2}{|c|}{$\begin{array}{c}\text { (2) } \\
\text { A Dep. }\end{array}$} & \multicolumn{2}{|c|}{$\begin{array}{c}\text { (3) } \\
\text { G Dep. }\end{array}$} & \multicolumn{2}{|c|}{$\begin{array}{c}(4) \\
\text { K Dep. }\end{array}$} & \multicolumn{2}{|c|}{$\begin{array}{c}\text { (5) } \\
\text { T Dep. }\end{array}$} & \multicolumn{2}{|c|}{$\begin{array}{c}(6) \\
\text { E Dep. }\end{array}$} & \multicolumn{2}{|c|}{$\begin{array}{c}\text { (7) } \\
\text { D Dep. }\end{array}$} & \multirow[t]{2}{*}{ F } & \multirow{2}{*}{$\begin{array}{l}\text { Post- } \\
\text { test }\end{array}$} \\
\hline & & $\mathrm{M}$ & SD & $\mathrm{M}$ & $\mathrm{SD}$ & $\mathrm{M}$ & $\mathrm{SD}$ & $\mathrm{M}$ & $\mathrm{SD}$ & M & $\mathrm{SD}$ & $\mathrm{M}$ & $\mathrm{SD}$ & $\mathrm{M}$ & $\mathrm{SD}$ & & \\
\hline 120 & 4.21 & 4.30 & .79 & 4.30 & .82 & 4.10 & .90 & 4.28 & .87 & 4.27 & .80 & 4.02 & .9 & 4.62 & .53 & $6.55 * * *$ & $4>3$ \\
\hline
\end{tabular}

It was found that more number of freshmen answered "Yes" rather than "No" to the questions on the interests in employment and the certainty of the future area of work, but to the questions on the enhancement of self-esteem and a passion to studying and releasing of fear, a similar number of freshmen or 2 to 4 more number of ones answered "Yes". At the G-department, 4 more number of freshmen answered "Yes" to the question on the interests in employment and 8 more number of them answered "No" to the question on the releasing of fear. In addition, 2 to 4 more or a similar number or the same number of freshmen answered "Yes" to the question on the enhancement of self-esteem, a passion to studying and the future area of work

At the K-department, much more number of students answered "Yes" to all of the questions. According to the statistical data obtained by separating the targets into male and female, both genders answered "Yes" to all of the questions, but in all areas, more number of males than female answered "No". It was found that there were especially a big difference between the answers of the participants and non-participants in the mentoring program regarding to the satisfaction levels with classmates, professors and departments and the enhancement of self-development.

Many of the freshmen participating in the mentoring program checked in the boxes, "Very Good" and "Good" in the areas of the satisfaction levels with classmates, professors and departments. On the other hand, It was found that more number of non-participants than participants answered "No Good" even though more number of non-participants checked in the box, "Good". Based on the results of the interviews for surveying the responses of the respondents, it was found that the mentoring course for freshmen is generally helpful for the enhancement of relationship between classmates and with professors even though the contents may be different depending on the discretionary authority of each professor and it is also helpful for the future of the students since they can listen to many kinds of advices on the prospect and potential of each department. 


\section{Conclusion and Discussion}

A change of this time in the university environment caused a sudden change from the existing supplier-oriented education into a consumer-oriented one. To comprehend the contents of the satisfaction with a department specifically has become very important for the university lives and career lives after the graduation of the university students[10]. Moreover, since a university is an institute playing an important role for increasing some personal talent to be applied correctly in a changing social environment, the personal relationship between students and the adaptation level to the university environment become important tasks most of all.

Many universities have introduced and are implementing a double major system, a faculty system and a mentoring system, etc. for the students to have their ego identity at each department and their adaptation to the university environment. Among such systems, the mentoring system is one attracting much attention from the people with its functions for new career development, adaptation to an organization and a method for satisfaction.

Currently, the identity of the Korean universities is threatened due to a change in the university entrance environment caused by a low birthrate and an increase in the drop-out rate of the students not adaptive to a major, etc[11]. To do this, in this study, the effects of the mentoring program by each advisor targeting freshmen at each rural university shall be examined and the adaptive ability of each to the university environment was analyzed.

Based on the results of this study, those freshmen showed very positive responses regarding to their satisfaction levels with academic courses, a help for the adaptation to the university environment, a help for the understanding of a major, a pride in each university, their interests in studying, their friendliness with professors and classmates and the enhancement of learning atmosphere, etc. This study is emphasizing the necessity of counseling by establishing some good relationship useful for guidance on freshmen of each university in the future by having all of the freshmen and the professor in charge to instruct those students closely while operating the mentoring program as an academic course in order to help the freshmen to adapt themselves to the university environment.

The mentoring program for freshmen is becoming a required course for liberal arts since the program was opened for the purpose of helping them to adapt themselves to the university lives at each department. As the results, it is considered that it is much helpful to improve the personal relationship and the prospect. However, some of students have a negative awareness of the mentoring course (by answering that they have not affected by the program at all.) 
It is analyzed that the parts of the program that cannot satisfy some of the freshmen must be improved with the advices from those students participating in the program.

Regarding to the question asking, "What do you think of whether the mentoring program for freshmen should be progressed continuously?" among the interview on the effects onto the university lives, there were some opinions that the relationship with classmates and professors will be improved if some departments give some classes in a more smooth atmosphere by giving a class outside rather than inside. And it was also found from an interview that the relationship of the freshmen at the department that has been on an excursion with the classmates became much better than those at the other department that has not been on an excursion[6]. Thus, it is judged that a future mentoring program should be developed in a way that the relationship between classmates is improved through a flexible instruction method, such as, an outdoor class, etc. and more smooth communication is exchanged through a more comfortable atmosphere.

Therefore, this study is meaningful to suggest some baseline data for preparing for some methods for complementing various policies and innovating education in order for the future Korean university freshmen to adapt themselves to the university environment due to a change in the university exam environment by analyzing the effects of the mentoring program onto the adaptation of the participants to the university environment after preparing for the mentoring program that can satisfy the demands of the university freshmen.

\section{References}

[1] D. Ahn, G. Park, K. J. Baek, and S. I. Chung, Academic motivation, academic stress, and perceptions of academic performance in medical students, Korean J Med Educ, (2007), Vol.19, pp.59-71.

[2] http://kosis.kr/statHtml/statHtml.do?orgId=101\&tblId=DT_1B81A17\&vw_cd=MT_ZTITLE\&list_id=A21\&seqNo 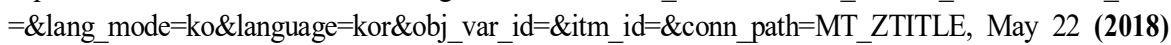

[3] http://www.index.go.kr/potal/main/EachDtlPageDetail.do?idx_cd=1541, Agu 31 (2017)

[4] https://m.blog.naver.com/PostView.nhn?blogId=jonychoi\&logNo=221124661724\&proxyReferer=https\%3A\%2F \%2Fwww.google.co.kr\%2F, Jun 30 (2018)

[5] D. Rachael and C. W. Rents, Freshmen Adaptation to University Life: Depressive Symptoms, Stress, and Coping, J. of Clinic Psychology, (2006), Vol.62, No.10, pp.1231-1244.

[6] http://www.ssunews.net/news/articleView.html?idxno=5720, Apr 3 (2017)

[7] http://smartincome.tistory.com/1330, Mar 4 (2017) 
A Study on Effects of Mentoring Education Program by Advisor onto Adaptation and Relationship of University Freshmen

[8] http://ntnews.co.kr/news/news_print.html?section=1\&category=5\&no=8153, Sep 3 (2013)

[9] http://www.usline.kr/news/articleView.html?idxno=9280, Mar 28 (2017)

[10] M. R. Lee, A Study on the Interpersonal Tendency and Perception about Marriage of University Students in the Community, Asia-pacific Journal of Psychology and Counseling, (2018), Vol.2, No.2, pp.37-42, http://dx.doi.org/10.21742/apjpc.2018.2.2.07

[11] OECD data. https://data.oecd.org/healthstat/life-expectancy-at-birth.htm, Nov 10 (2017) 